\section{FUNERAL OF MR. SPOTTISWOODE}

THE funeral of the late President of the Royal Society on Thursday last was impressive and solemn, and was a fitting end to the life that had passed away.

We take from the Times the following account of the general arrangements of the funeral :-

A large number of those who were present assembled in the Jerusalem Chamber, which the Dean had kindly placed at the disposal of the family. Those who by courtesy were styled pall-bearers met here-Dr. Evans, Vice-President and Treasurer of the Royal Society, the Marquis of Salisbury (Chancellor of the University of Oxford), Earl Granville (Chanceilor of the University of London), Mr. Childers, Sir W. Siemens, the Duke of Northumberland, Sir Frederick Leighton, P.R.A., the Master of the Stationers' Company, Lord Aberdare, Sir John Lubbock, Mr. E. J. Stone, Sir Bartle Frere, Prof. Flower, Sir W. Armstrong, and, representing departments in the firms with which the name of Spottiswoode is connected, Mr. Shinn, Mr. Millwood, Mr. Carey, Mr. White, Mr. Howe, Mr. Wilson, Mr. Hamilton, and Mr. Straker. Others, who went first to the Jerusalem Chamber, were the Archbishop of York, the Bishop of Lincoln, Mr. Mundella, M.P., Mr. ShawLefevre, M.P., the Dean of Christ Church, the Master of Balliol (Prof. Jowett), the Archdeacon of Maidstone, Sir Frederick Bramwell, Sir Richard Cross, M.P., Mr. Warren De La Rue, Sir Frederick Evans, Sir Joseph Fayrer, Sir James Caird, Lord Claud Hamilton, the Hon. George Brodrick (Warden of Merton), Mr. W. H. Smith, M.P., Mr. W. E. Forster, M.P., Sir Charles Dilke, General Sir H. Rawlinson, Sir James Paget, Mr. Irving, Prof. Huxley, Sir Joseph Hooker, Mr. Lecky, Sir Richard Temple, and Mr. J. Norman Lockyer. Some again, among whom were Lord O'Hagan, Sir Walter Stirling, Sir Henry Barkly, Sir James Cockle, the Dean of Wells, Mr. Philip Magnus, Director of the City and Guilds of London Institute, Mr. Trueman Wood, Secretary, and Mr. Wheatley, Assistant Secretary of the Society of Arts, Mr. Symons, F.R.S., of the Meteorological Society, and Sir John Kennaway, M.P., at once took their places in the choir or south transept, the seats in the north transept being reserved for employés of Messrs. Eyre and Spottiswoode and Messrs. Spottiswoode and Co.

Besides those who have already been named, the list of mourners invited to attend in the Jerusalem Chamber included the following gentlemen, of whom nearly all were present :-

Mr. Andrew Cockerell (representing his Royal Highness the Prince of Wales), the Lord Mayor, Mr. Gladstone, the Ameri can Minister, Count D'Aunay, Count Munster, the Lord Chancellor, the Earl of Northbrools, the Duke of Argyll, the Duke of Buccleuch, the Earl of Derby, the Earl of Ducie, the Earl of Dufferin, Earl Sydney, Sir Stafford Northcote, M.P., Lord Sherbrooke, Earl Spencer, Sir Frederick Abel, C.B., Capt. Abney, R.E., Prof. Acland, M.D., Prof. J. Adams, LL.D., Prof, W. Adams, M.A., Sir Georye Airy, K.C.B., Prof. Alt man, M.D., Prof. C. Babington, M.A., Mr. John Ball, M.A. Mr. P. W. Barlow, F.G.S., the Earl of Rosse, Lord Chelmsford, Lord Eustace Cecil, Lord Lawrence, Lord Reay, the Marquis of Hartington, M.P., Lord Rayleigh, Lord Colin Campbell, Lord Carlingford, the Earl of Kimberley, Earl Amherst, Lord Houghton, the Bishop of London, the Dean of St. Paul's, the Bishop of Truro, the Dean of Salisbury, Mr. W. J. Farrar, Mr. W. H. Barlow, Mr. J. F. Bateman, F.G.S., Prof. Beale, M.D., Mr. I. L. Bell, F.C.S., Sir J. R. Bennett, M.D., Mr. George Bentham, F.L.S., Mr. Beresford-Hope, M.P., Sir Henry Bessemer, Mr. H. W. Blake, M.A., General Boileau, F.R.A.S., the Rev. T. G. Bonney, M.A., Mr. W. Bowman, LL.D., Mr. T. L. Brunton, M.D., Mr. G. B. Buckton, F.G.S., Sir C. J. Bunbury, Lord Cardwell, F.G.S., Dr. W. B. Carpenter, C.B., Mr. W. Carruthers, V.P.L.S., Prof, Cayley, V.P.K.A.S., Mr. Chamberlain, General Clark, R.A., Prof. R. B. Clifton, M.A., the Earl of Crawford and Balcarres, Prof. W. Crookes,
F.C.S., Mr. T. B. Curling, F.R.C.S., Prof. G. H. Darwin, M.A., Prof. W. B. Dawkins, M.A., Prof. H. Debas, Ph.D., Prof. J. Dewar, M.A., Prof. Duncan, M. B., Mr. Edwin Dukin, F.R.A.S., Mr. W. T. Dyer, M.A., Sir W. Elliott, K.C.S.I., Mr. A. J. Ellis, B.A., Mr. Arthur Farre, M.D., Mr. Faw cett, M.P., Mr. James Fergusson, D.C.L., Prof. G. C. Foster, B.A., Dr. M. Foster, Prof. E. Frankland, D.C.L., Capt. Douglas Galton, C.B., Mr. Francis Galton, M.A., Dr. J. H. Gladstone, Mr. J. Glaisher, F.R.A.S., Mr. R. Godwin Austen, F.G.S., the Right Hon. J. G. Goschen, M.P., Lieut.-Col. J. Grant, C. B., the Right Hon. Sir W. H. Gregory, K.C.M.G., Sir W. Grove, Sir W. Gull, Mr. Albert Gunther, M.A., Prof. F. Guthrie, F.G.S., Mr. W. A. Guy, M.B., Sir W. V. Harcourt, M.P., Mr. A. G. Harcourt, V.P.C.S., Sir John Hawkshaw, Mr. Thomas Hawksley, M.I.C.E., Mr. R. B. Haywood, M.A., Mr. P. G. Hewett, F.R.C.S., Mr. James Heywood, F.G.S., Dr. T. A. Hirst, Prof. A. W. Hoffman, Ph.D., Mr. J. Hopkinson, M.A., Dr. W. Huggins, Mr. J. W. Hulke, F.R.C.S., Prof. Humphrey, M.D., Dr. J. H. Jackson, Dr. J. G. Jeffreys, Sir W. Jenner, K.C.B., Dr. J. C. Joule, Sir John and Lady Kennaway, Admiral Sir Astley Cooper Key, K.C.B., Prof. Ray Lankester, M.A., General Sir J. H. Lefroy, C.B., Mr. Joseph Lister, F.R.C.S., Admiral Sir F. L. M'Clintock, Sir H. Sumner Maine, LL.D., Prof. Marshall, V.P.R.C.S., Prof. N. S. Maskelyne, M.A., Mr. C. W. Merrifield, Mr. Alfred Newton, M.A., Prof, Odling, Mr. Daniel Oliver, F.L.S., Prof. Owen, C.B., Dr. John Percy, Mr. W. H. Perkin, C.S., Major-Gen. Pitt-Rivers, Sir Lyon Playfair, M.P., Dr. W. Pole, Mr. W. H. Preece, C.E., Prof. J. Prestwich, M.A., the Rev. Bartholomew Price, the Rev. Charles Pritchard, M.A., Dr. Quain, Sir A. C. Ramsay, LL.D., Prof. Osborne Reynolds, Admiral Sir G. H. Richards, C.B., Mr. G. J. Romanes, M.A., Prof. H. Roscoe, B.A., Mr. Osbert Salvin, M.A., Prof. Sanderson, Mr. P. L. Sclater, M. A., Mr. R. H. Scott, M.A., Mr. John Simon, C. B., Mr. W. W. Smylh, M. A., General W. J. Smythe, Mr. H. C. Sorby, LL.D., Mr. H. T. Stainton, F.L.S., Prof. Balfour: Stewart, M.A., Prof. G. G. Stokes, M.A., General R. Strachey, R.E., Prof. J. J. Sylvester, M. A., Dr. Allen Thomson, Sir W. Thomson, LL.D., Mr. J. Todhunter, M.A., Prof. Tyndall, Dr. A. W. Williamson, Mr. W. H. Pollock, Mr. E. Bunbury, the Rev. B. Compton, Mr. Horace Davey, Q.C., M.P., the Head Master of Rugby, the Provost of Eton, the Head Master of Eton, the Hon. Ralph Dutton, the Hon. Robert Butler, Mr. Osborne Morgan, M.P., the Bishop of Exeter, Sir Louis Pelly, Sir Henry Thompson, Sir James Lacaita, Mr. J. Boehm, Mr. A. Milman, Mr. W. Hasseltine, Mr. F. Pollock, Mr. Pascoe Grenfell, Mr. T. Woolner, Mr. Lawrence T. Cave, Mr. T. H. Gordon, the Rev. W. H. Milman, Mr. T. Chenery, Mr. W. F. Burton, Mr. Douglas Freshfield, General Hutt, Dr. W. Grey, Dr. Priestly, Prof. Bryce, M.P., Mr. W. C. Cartwright, Sir Julian Goldsmid, Sir Louis Malet, Sir Rutherford Alcock, Sir Arthur Hobhouse, Sir Charles Mills, M.P., General Sir M. M'Murdo, General Sir Patrick Grant, Sir Charles Trevelyan, Sir James Stephen, Sir Charles Bowen, Lord G. Hamilton, M.P., the Recorder of London, Alderman Sir S. H. Waterlow, M.P., the Wardens of the Stationers' Company, Col. Donnelly, Prof. Ruskin, Cardinal Manning, a deputation from the Chemical Society, Mr. J. G. Dodson, M.P., Dr. Cumberbatch, Dr. Gibbons, Mr. Robert Browning, Mr. E. Chinnery, Mr. J. A. Froude, Sir R. Lingen, Mr. Herbert Spencer, the Dean of Llandaff, Sir Harry Verney, M.P., Lord Wolseley, Mr. Cyril Graham, Mr. Charles Eastlake, Mr. George Frere, F.R.S., Mr. Talfourd Ely, Sir Thomas Pears, Prof. Leone Levi, Prof. Max Muiller, Mr. Frederick Veruey, Mr. H. C. Hughes, and Major Gordon.

The body was borne from the house in Grosvenor Place to the Abbey on an open funeral car drawn by four horses. In the carriages immediately following the funeral car were Mrs. Spottiswoode, Mr. Hugh Spottiswoode, Mr. G. A. Spottiswoode, Mr. Cyril Spottiswoode, Mr. Rate, Mrs. George Spottiswoode, Miss Spottiswoode, Miss Augusta Spottiswoode, Mr. Arthur Brandreth, Mrs. Brandreth (sister of Mr. Spottiswoode), Mr. and Mrs. G. Noble Taylor, Mr. T. P. Beckwith, Miss Ellen Arbuthnot, Miss Mabel Spottiswoode, Mr. Adrian Spottiswoode, Mr. Norton Longman, Miss Longman, Miss Elizabeth Spottiswoode, Mr. Eyre, Mr. and Mrs. R. M. Bray, Mr. Frederick Arbuthnot, Miss Margaret and Master John Arbuthnot, Mrs. Beckwith, Mr. Sydney Beckwith, Mrs. 
Jervoise, and Mr. Rate, jun. The servants came next in two carriages, and after the empty family carriage, the carriage of his Royal Highness the Prince of Wales, and then those of friends of the family.

At the entrance to the cloisters a company of the and London Rifle Volunteer Regiment, formed of employés of the Spottiswoode establishments, stood with arms reversed as the procession passed through to the Abbey. At the West Cloister door, choristers, scholars, and clergy, the Rev. Floot Jones, precentor, the Rev. John Troutbeck, Minor Canon, Canon Rowsell, Canon Barry, Archdeacon Farrar, and the Dean, met the body. Immediately behind the chief mourners, and in front of those from the Jerusalem Chamber came, by special invitation of the family, Earl Stanhope, the Earl of Dalhousie, Sir F. W. Pollock, and Mr. J. F. Moulton; then Mr. Andrew Cockerell, representing the Prince of Wales, and among those from the Jerusalem Chamber, Mr. George Busk, Vice-President of the Royal Institution. The coffin, still covered with its lovely floral tributes, was placed under the lantern, while the goth Psalm was sung to Purcell's Burial Chant, and the lesson was read by Canon Duckworth. As the notes of the anthem died away the body was borne to its last resting-place, near the grave of Archbishop Spottiswood. So great was the congregation of mourners, that not half the number could find standing room in the narrow aisle in which the grave is made. The Dean said the "Committal" and the prayers, and after the singing of Bishop Wordsworth's well-known hymn, "Hark, the sound of holy voices, chanting at the crystal sea," the Dean pronounced the blessing, and the mourners, casting into the grave the wreaths and bunches of flowers which many of them had carried, slowly dispersed. Dr. Bridge played the "Dead March" in "Saul" at the conclusion of the funeral service. The inscription on the plate of the coffin, which for sole decoration bore a Latin cross of brass, was-

\section{WILLIAM SPOTTISWOODE, \\ Born January II, 1825 \\ Died June 27, 1883 .}

A sermon in memoriam was preached in the Abbey by the Dean on Sunday afternoon.

\section{THE ECLIPSE PARTY}

I E'

ETTERS have been received from the English and American members of the above, giving some details which we think may prove of interest to our readers.

Leaving England on February 17 in the s.s. Medway the English observers niade a calm passage to Colon. Here they met the American party, consisting of Prof. Holden, Dr. Hastings, Mr. Rockwell, Mr. Preston, Lieut. Brown, and Mr. Upton, to which it will be remembered they were to be attached. The united party then proceeded to Panama, and took ship in the Bolivia for Callao, where they arrived on March 2o. Early the following morning the instruments and baggage were removed to the U.S.S. Hartford, in which the voyage from thence was to be made, and the party left Callao about five o'clock on the evening of March 22, sighting Caroline Island, the spot selected for the observations, on April 20 . Although named Caroline Island it is not a single island, but a lowlying chain of coral islets which enclose a central lagoon. The ring of islets is about seven and a half miles in length, and one and a half in breadth The island like most of its kind is of value on account of its stores of guano, and its cocoanut produce, being leased to Messrs. Houlder Brothers of 146 , Leadenhall Street, whose agent at intervals visits this, and other Pacific coral islands leased to the firm. On the arrival of the Hartford a boat under the charge of Lieut. Qualtrough put off to make a tour of inspection, returning with the intelligence that there were two large empty frame houses, several smaller ones, and seven inhabitants-four men, one woman, and two children-who had come thither from Tahiti two montbs previously. A site having been selected by Prof. Holden for the erection of the observatory, the work of disembarkation commenced. This was a matter of great difficulty, the nature of the coast preventing even the small ship's boats approaching within several hundred yards of the shore. The boats had first to run in through a narrow opening in the reef, the boxes had then to be carried through fifty yards or so of water, varying in depth from two to three feet, next over about fifty yards of sharp irregular coral rock that cut the men's shoes to pieces, and finally to be carried up a soft sandy beach for upwards of a quarter of a mile. However, the landing was effected without accident, and the observers took possession of their various quarters.

The English observers report that the house in which they were located was a very comfortable one, containing a kitchen, dining-room, bed-room, bath-room, and storeroom, and a large laboratory. Mr. Rockwell, one of the American observers, was fortunate enough to obtain the luxury of a bed. Mr. Upton, another of the party, had to be content with a table, whilst the rest swung their hammocks and cots in the verandah, an arrangement which, while possessing perhaps advantages of its own when the weather was fine, was not altogether the best when the nights were wet. Still the observers were not uncomfortable; and if they did not "fare sumptuously every day," yet, with abundance of fish and cocoanuts, they did not live altogether badly.

The weather, with the exception of one severe rainstorm, was pleasant during the sojourn of the observers, although nearly every day slight showers were brought to the island by flying clouds.

On the evening of the 22nd, just as the Hartford was casting off for Tahiti, L'Éclaireur came in with the French expedition, consisting of MM. Janssen, Trouvelot, Palisa, and Tacchini on board.

The preparations for the eclipse proceeded briskly, and by April 28 the siderostat, equatorial, and photoheliograph were erected and adjusted in position. The spectroscopes were next taken in hand, and the rating of the clocks proceeded with. This took some time; but mat ters had so far advanced by May I that from that date, with the exception of May 4, when the weather was wet, two rehearsals of the observations were made daily, one at 7, the other at II.30 a.m. Messrs. Preston and Brown of the U.S. Coast and Geodetic Survey during this period made pendulum observations.

By the evening of May 3 the photographers were nearly ready to take trial plates, and these they hoped to obtain the following day. The hitherto fine weather, however changed, and before noon the next day five inches of rain had fallen, and the photographic dark room which had been erected was destroyed, all the dye being washed out of the ruby curtains and window. This damage being repaired, an attempt was made to obtain trial plates the next day, but the length of time occupied in rehearsing the observations, and the still unsettled state of the weather, prevented this being done. The early morning of the eclipse found the weather in the same unsettled state; about nine o'clock, however, the clouds began to disperse themselves, and by ten o'clock the sky was moderately clear. After the first contact the lenses were dusted, the slits of the spectroscopes cleaned, and the adjustments finally inspected.

With regard to the work of observation itself, this was done in accordance with the programme laid down before the observers left England, although the time-table of exposures was slightly departed from to meet the circumstances of the case, as, for instance, a greater length of totality than was expected, the duration being five minutes twenty-five seconds. During the eclipse the direction and velocity of the wind remained constant, 